\title{
Development Performance of Economic Growth Typology in Southeast Sulawesi Province
}

\author{
Yohanes Boni \\ Department of Economic and Development Studies, Halu Oleo University, Indonesia \\ Corresponding author email: yohanis.boni@gmail.com \\ Muhammad Zamrun Firihu \\ Department of Physics, Halu Oleo University, Indonesia \\ H. Pasrun Adam \\ Department of Mathematics, Halu Oleo University, Indonesia \\ Rahmat Sewa Suraya \\ Department of Oral Tradition Halu Oleo University, Indonesia \\ Herdiansyah \\ Department of Economic and Development Studies, Halu Oleo University, Indonesia
}

\begin{abstract}
This research was conducted in Southeast Sulawesi Province in 2020. The purpose of this study was to determine the economic base sector as a leading sector, to determine the effect of national economic growth on economic growth in Southeast Sulawesi, and to determine advanced and fast-growing sectors, and advanced but depressed sectors in Southeast Sulawesi. Southeast Sulawesi Province. The results of the analysis show: (1) Location Quotien (LQ) analysis of the basic sectors as the leading sectors are: (a) Agriculture, forestry and fisheries sectors $L Q$ of 1.83 or $L Q>1$. (b) The mining and quarrying sector $L Q$ is 2.65 or $L Q>1$. (c) The sector of water management, waste management, waste management and recycling of $L Q$ is 2.65 or $L Q>1$. (d) The construction sector $L Q$ is 1.30 or $L Q>1$. (e) The transportation and warehousing sector is $L Q 1.13$ or $L Q>1$. (f) Government administration, defense and social security sectors $L Q 1.54$ or $L Q>1$. (g) Education services sector $L Q$ of 1.53 or $L Q>1$.
\end{abstract}

Keywords---advanced and developing, basic sector, development, economic growth, performance.

\section{Introduction}

Development performance is influenced by the typology of economic growth in a region, where economic growth will result in the per capita income of the population of a region increasing through a multiplier effect process from the implementation of development that occurs continuously (Schumann et al., 2012; Lopez-Carreiro \& Monzon, 2018). The work plan of the Southeast Sulawesi Provincial government focuses on accelerating development with an emphasis on building a strong economic structure based on competitive advantages in various regions supported by quality and competitive human resources. Based on the work plan, the economic growth achievement of Southeast Sulawesi Province in 2019 was 6.51 percent, and the average economic growth in Southeast Sulawesi for the last 5 (five) years was 6.42 or above the average national economic growth of 5, 02 percent (Faucheux \& Nicolaï, 2011; Dong et al., 2014).

The increase in economic growth increased development performance in Southeast Sulawesi Province, including: (1) The number of poor people in 2017 was 331.71 thousand or 12.81 percent, in 2019 the number of poor people 
decreased by 246.78 thousand or 11.04 percent. The rural poor population in 2017 was 274.11 thousand or 15.31 percent, in 2019 the rural poor population decreased by 46.73 thousand to 227.38 thousand or 13.77 percent. (2) Southeast Sulawesi's Human Development Index (HDI) in 2013 was 67.55 percent, in 2019 it increased to 71.20 percent, the HDI achievement of Southeast Sulawesi has approached the National HDI of 71.92 percent. During the period 2013 to 2019, the Human Development Index (HDI) grew by 0.84 percent per year. (3) In 2019 the level of expenditure inequality of the Southeast Sulawesi population as measured by the Gini Ratio was 0.3923 . This figure decreased by 0.0076 points when compared to the 2017 Gini Ratio of 0.3999 .

The added value contribution created by each business field illustrates the economic structure of Southeast Sulawesi Province. The business fields that had the largest contribution to the improvement of the development performance of Southeast Sulawesi Province were: (1) Agriculture, forestry, and fisheries by 23.73 percent, (2) Mining and excavation by 21.22 percent, (3) Construction by 13.69 percent, (4) Wholesale and retail trade, car, and motorcycle reparation 12.76 percent, (5) Processing industry 6.24 percent (Heriyanto et al., 2020). The five business fields have a very dominant contribution, namely 77.64 percent of the GRDP of Southeast Sulawesi Province (Park \& Bae, 2004; Geels \& Schot, 2007). The five business field sectors are basic sectors that have the potential to increase economic growth and increase the development performance of Southeast Sulawesi Province, so it is necessary to develop strategies and policies that place these five sectors as the leading sectors in economic development in the Southeast Sulawesi Province.

\section{Method}

Location Quotient $(L Q)$ analysis

Mathematically the LQ formula is as follows:

$$
L Q=\frac{x i / P D R B}{X i / P N B}
$$

Annotation:

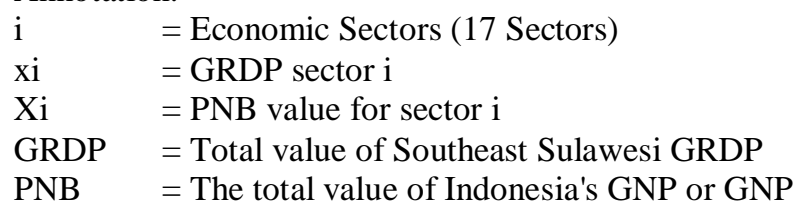

Shiff-share analysis

Mathematically, the formula for Shift Share Analysis is as follows (Tarigan, 2005):

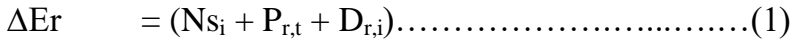

$$
\begin{aligned}
& \mathrm{Ns}_{\mathrm{i}, \mathrm{t}} \quad=\mathrm{E}_{\mathrm{r}, \mathrm{i}, \mathrm{t}-\mathrm{n}}\left(\mathrm{EN}_{\mathrm{t}} / \mathrm{EN}_{\mathrm{t}-\mathrm{n}}\right)-\mathrm{E}_{\mathrm{r}, \mathrm{i}, \mathrm{t}-\mathrm{n}} \ldots \ldots \ldots \ldots \ldots \ldots . .(2) \\
& \mathrm{P}_{\mathrm{r}, \mathrm{i}, \mathrm{t}}=\mathrm{E}_{\mathrm{r}, \mathrm{i}, \mathrm{t}-\mathrm{n}}\left[\left(\mathrm{EN}_{\mathrm{i}, \mathrm{t}} / \mathrm{EN}_{\mathrm{i}, \mathrm{t}-\mathrm{n}}\right)-\left(\mathrm{EN}_{\mathrm{t}} / \mathrm{EN}_{\mathrm{t}-\mathrm{n}}\right)\right] \ldots \text { (3) } \\
& \mathrm{D}_{\mathrm{r}, \mathrm{i}, \mathrm{t}} \quad=\left(\mathrm{E}_{\mathrm{r}, \mathrm{i}, \mathrm{t}}-\left(\mathrm{EN}_{\mathrm{i}, \mathrm{t}} / \mathrm{EN}_{\mathrm{i}, \mathrm{t}-\mathrm{n}}\right)-\mathrm{E}_{\mathrm{r}, \mathrm{i}, \mathrm{t}-\mathrm{n}}\right) \ldots \ldots \ldots \ldots \ldots . .(4)
\end{aligned}
$$

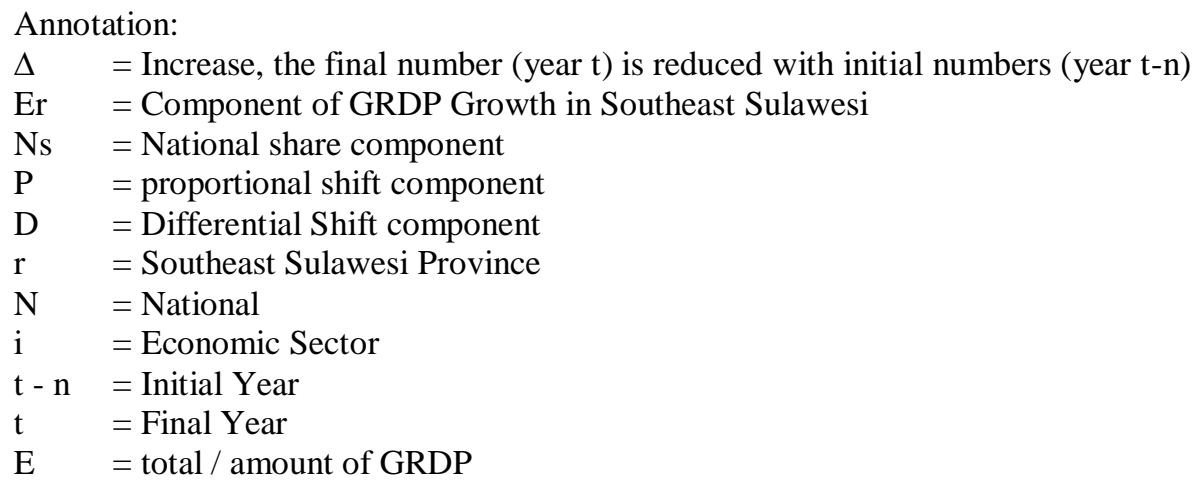


Klassen typology analysis

Regional typology (Klassen typology) is used to describe the typology and structure of economic growth in each region. Then divided into four quadrants (Emilia, 2006), namely:

Table 1

Klassen typology analysis

\begin{tabular}{|c|c|c|}
\hline \multirow{2}{*}{$\begin{array}{l}\text { PDRB Per Capita } \\
\text { Growth rate }\end{array}$} & \multirow[t]{2}{*}{$Y i-Y n$} & \multirow[t]{2}{*}{$\mathrm{Yi}<\mathrm{Yn}$} \\
\hline & & \\
\hline $\mathrm{Ri}-\mathrm{Rn}$ & $\begin{array}{l}\text { Advanced and Fast- } \\
\text { Growing Areas }\end{array}$ & Fast Developing Areas \\
\hline $\mathrm{Ri}<\mathrm{Rn}$ & $\begin{array}{l}\text { Developed But } \\
\text { Depressed Districts }\end{array}$ & $\begin{array}{l}\text { Relatively } \\
\text { Disadvantaged Areas }\end{array}$ \\
\hline
\end{tabular}

Annotation:

Ri : Regional GDP Growth Rate i

$\mathrm{Rn}$ : National GDP Growth Rate

$\mathrm{Yi} \quad$ : District per capita income i

Yn : National per capita income

\section{Research Result}

GRDP growth in Southeast Sulawesi province

The economy of Southeast Sulawesi Province from 2015 to 2019 shows the progress that continues to increase. The increase in the value of GDP in Southeast Sulawesi shows a positive development with the increase in production from all economic business fields and the effect of the increase in the price of commodities produced.

Table 2

Contribution of business fields to PDRB Prov. Southeast Sulawesi, 2015-2019

\begin{tabular}{|c|c|c|c|c|c|c|}
\hline No. & Business field & 2015 & 2016 & 2017 & 2018 & 2019 \\
\hline 1. & Agriculture, Forestry and Fisheries & 24,03 & 24,32 & 24,1 & 23,96 & 23,73 \\
\hline 2. & Mining and excavation & 20,88 & 19,38 & 20,7 & 20,91 & 21,22 \\
\hline 3. & Processing industry & 5,95 & 6,09 & 6,13 & 6,12 & 6,24 \\
\hline 4. & Procurement of Electricity and Gas & 0,03 & 0,04 & 0,04 & 0,04 & 0,04 \\
\hline 5. & $\begin{array}{l}\text { Water Supply, Waste Management, } \\
\text { Waste and Recycling }\end{array}$ & 0,20 & 0,20 & 0,18 & 0,17 & 0,17 \\
\hline 6. & Construction & 13,33 & 14,02 & 13,3 & 13,49 & 13,69 \\
\hline 7. & $\begin{array}{l}\text { Wholesale and Retail Trade; Car and } \\
\text { Motorcycle Repair }\end{array}$ & 11,99 & 12,39 & 12,5 & 12,64 & 12,76 \\
\hline 8. & Transportation and Warehousing & 4,45 & 4,49 & 4,52 & 4,57 & 4,42 \\
\hline 9. & $\begin{array}{l}\text { Provision of Accommodation and Food } \\
\text { and Drink }\end{array}$ & 0,59 & 0,59 & 0,58 & 0,57 & 0,56 \\
\hline 10. & Information and Communication & 1,83 & 1,85 & 1,85 & 1,82 & 1,79 \\
\hline 11. & Financial Services and Insurance & 2,32 & 2,49 & 2,44 & 2,35 & 2,35 \\
\hline 12. & Real Estate & 1,60 & 1,55 & 1,49 & 1,40 & 1,34 \\
\hline 13. & Company Services & 0,21 & 0,21 & 0,20 & 0,20 & 0,20 \\
\hline 14. & $\begin{array}{l}\text { Mandatory Government } \\
\text { Administration, Defense and Social } \\
\text { Security }\end{array}$ & 5,69 & 5,37 & 5,15 & 5,09 & 4,89 \\
\hline 15. & Education Services & 4,55 & 4,70 & 4,54 & 4,51 & 4,47 \\
\hline
\end{tabular}




\begin{tabular}{|c|c|c|c|c|c|}
\hline Health Services and Social Activities & 0,96 & 0,94 & 0,91 & 0,90 & 0,91 \\
\hline Other services & 1,39 & 1,37 & 1,30 & 1,26 & 1,22 \\
\hline Gross Regional Domestic Product & 100,00 & 100,00 & 100,00 & 100,00 & 100,00 \\
\hline
\end{tabular}

Source: BPS Prov. Southeast Sulawesi in 2020

Table 2 above shows that the business fields that contributed the most to the formation of GRDP of Southeast Sulawesi Province were: (1) Agriculture, Forestry, and Fisheries amounting to 23.73 percent, (2) Mining and Excavation by 21.22 percent, (3) Construction 13.69 percent, (4) Wholesale and Retail Trade; Car and motorcycle repairs by 12.76 percent, and (5) processing industries by 6.24 percent. The five business sectors have been the driving force for economic growth in Southeast Sulawesi Province during the period 2015 to 2019. The rate of economic growth can be seen from changes in the value of GRDP at constant (real) prices, which is one of the indicators of development progress in Southeast Sulawesi Province. The economic growth of Southeast Sulawesi Province according to business fields for the period 2015 to 2019 is shown in the following Table 3.

Table 3

GRDP Growth Prov. Southeast Sulawesi according to business fields, 2015 - 2019

\begin{tabular}{|c|c|c|c|c|c|c|}
\hline No. & Business field & 2015 & 2016 & 2017 & 2018 & 2019 \\
\hline 1. & Agriculture, Forestry and Fisheries & 0,11 & 7,66 & 5,76 & 6,37 & 5,02 \\
\hline 2. & Mining and excavation & 9,87 & 0,29 & 12,77 & 6,85 & 7,52 \\
\hline 3. & Processing industry & 7,73 & 8,90 & 6,38 & 5,87 & 9,13 \\
\hline 4. & Procurement of Electricity and Gas & 7,46 & 5,70 & 5,92 & 1,52 & 6,89 \\
\hline 5. & $\begin{array}{l}\text { Water Supply, Waste Management, Waste } \\
\text { and Recycling }\end{array}$ & 2,80 & 8,91 & 0,12 & 5,70 & 3,94 \\
\hline 6. & Construction & 14,03 & 7,54 & 3,16 & 6,64 & 7,00 \\
\hline 7. & $\begin{array}{l}\text { Wholesale and Retail Trade; Car and } \\
\text { Motorcycle Repair }\end{array}$ & 8,73 & 10,1 & 6,80 & 6,63 & 7,75 \\
\hline 8. & Transportation and Warehousing & 7,86 & 11,6 & 7,24 & 8,76 & 4,38 \\
\hline 9. & $\begin{array}{l}\text { Provision of Accommodation and Food and } \\
\text { Drink }\end{array}$ & 7,90 & 7,36 & 6,16 & 6,69 & 4,94 \\
\hline 10. & Information and Communication & 7,11 & 9,76 & 8,43 & 8,20 & 7,83 \\
\hline 11. & Financial Services and Insurance & 7,72 & 15,1 & 4,53 & 2,16 & 6,96 \\
\hline 12. & Real Estate & 4,80 & 0,88 & 4,17 & 2,58 & 3,83 \\
\hline 13. & Company Services & 10,27 & 8,17 & 5,98 & 5,82 & 5,21 \\
\hline 14. & $\begin{array}{l}\text { Government Administration, Compulsory } \\
\text { Social Security and defense }\end{array}$ & 5,06 & 2,15 & 4,10 & 3,73 & 3,59 \\
\hline 15. & Education Services & 6,68 & 9,91 & 3,03 & 7,59 & 7,00 \\
\hline 16. & Health Services and Social Activities & 6,38 & 6,15 & 3,41 & 6,86 & 8,41 \\
\hline 17. & Other services & 7,08 & 7,47 & 2,74 & 5,61 & 4,57 \\
\hline \multicolumn{2}{|c|}{ Gross Regional Domestic Product } & 6,88 & 6,51 & 6,76 & 6,42 & 6,51 \\
\hline
\end{tabular}

Source: BPS Prov. Southeast Sulawesi, 2020

Table 3 above shows the average economic growth of Southeast Sulawesi from 2015 to 2019 of 6.61 percent. This growth rate indicates an acceleration of economic progress compared to Indonesia's growth of 5.02 percent. The economic sector experiencing an accelerated growth occurred in the manufacturing sector, namely 9.13 percent, the health services business sector and Social Activities by 8.41 percent; large and retail trade business fields; Car and motorcycle repair at 7.75 percent; Mining and quarrying business fields 7.52 percent; construction business field 7.00 percent; the Financial Services and Insurance business field 6.96 percent; and the electricity and gas supply business field of 6.89 percent; and Real Estate business field of 3.83 percent. This business field has had a growth acceleration during the period 2015 to 2019 .

\section{Location Quotient (LQ) analysis}

LQ analysis is one of the approaches used in the basic economic model as a first step in understanding the activity sectors that trigger economic growth in Southeast Sulawesi Province. LQ analysis is used to discuss economic conditions, 
identify the specialization of economic activities for each business field to get an idea of determining the base sector as the leading sector in Southeast Sulawesi Province.

Table 4

Location Quotient (LQ) Analysis Results from 2015 - 2019

\begin{tabular}{|c|c|c|c|c|c|c|c|}
\hline No. & Business field & 2015 & 2016 & 2017 & 2018 & 2019 & Information \\
\hline 1. & Agriculture, Forestry and Fisheries & 1.78 & 1.83 & 1.83 & 1.86 & 1.85 & Base \\
\hline 2. & Mining and excavation & 2.54 & 2.42 & 2.67 & 2.76 & 2.89 & Base \\
\hline 3. & Processing industry & 0.28 & 0.29 & 0.29 & 0.29 & 0.30 & Non Basis \\
\hline 4. & Procurement of Electricity and Gas & 0.05 & 0.05 & 0.05 & 0.05 & 0.05 & \multirow{2}{*}{$\begin{array}{l}\text { Non Basis } \\
\text { Base }\end{array}$} \\
\hline 5. & $\begin{array}{l}\text { Water Supply, Waste Management, } \\
\text { Waste and Recycling }\end{array}$ & 3.90 & 2.48 & 2.33 & 2.31 & 2.22 & \\
\hline 6. & Construction & 1.32 & 1.35 & 1.28 & 1.27 & 1.27 & \multirow{2}{*}{$\begin{array}{l}\text { Base } \\
\text { Non Basis }\end{array}$} \\
\hline 7. & $\begin{array}{l}\text { Wholesale and Retail Trade; Car and } \\
\text { Motorcycle Repair }\end{array}$ & 0.89 & 0.95 & 0.95 & 0.95 & 0.97 & \\
\hline 8. & Transportation and Warehousing & 1.12 & 1.17 & 1.14 & 1.14 & 1.10 & \multirow{2}{*}{$\begin{array}{l}\text { Base } \\
\text { Non Basis }\end{array}$} \\
\hline 9. & $\begin{array}{l}\text { Provision of Accommodation and Food } \\
\text { and Drink }\end{array}$ & 0.19 & 0.19 & 0.19 & 0.19 & 0.19 & \\
\hline 10. & Information and Communication & 0.48 & 0.49 & 0.48 & 0.48 & 0.46 & Non Basis \\
\hline 11. & Financial Services and Insurance & 0.56 & 0.59 & 0.57 & 0.55 & 0.55 & Non Basis \\
\hline 12. & Real Estate & 0.57 & 0.54 & 0.53 & 0.52 & 0.51 & Non Basis \\
\hline 13. & Company Services & 0.13 & 0.13 & 0.12 & 0.12 & 0.11 & Non Basis \\
\hline 14. & $\begin{array}{l}\text { Mandatory Government Administration, } \\
\text { Defense and Social Security }\end{array}$ & 1.60 & 1.56 & 1.56 & 1.53 & 1.46 & Base \\
\hline 15. & Education Services & 1.51 & 1.56 & 1.52 & 1.54 & 1.53 & Base \\
\hline 16. & Health Services and Social Activities & 0.94 & 0.91 & 0.86 & 0.85 & 0.84 & Non Basis \\
\hline 17. & Other services & 0.92 & 0.90 & 0.84 & 0.80 & 0.75 & Non Basis \\
\hline
\end{tabular}

Source: BPS Prov. Southeast Sulawesi 2020 (Data processed and analyzed)

Table 4 above shows the results of the Location Quotient (LQ) analysis from 2015 to 2019. The results of the analysis show that the basic sectors as the leading sectors during the 2015-2019 period in Southeast Sulawesi Province are: (1) Agriculture, forestry, and fisheries sectors have an average -The average LQ value is 1.83 or LQ> 1. (2) The mining and quarrying sector has an average LQ value of 2.65 or LQ> 1. (3) The water management, waste management, waste management, and recycling sectors have an average LQ value of 2.65 or LQ> 1. (4) The construction sector has an average LQ value of 1.30 or LQ>1. (5) The transportation and warehousing sectors have an average $L Q$ value of 1.13 or LQ> 1. (6) The government administration, defense, and social security sectors have an average LQ value of 1.54 or LQ> 1. (7) The education services sector has an average LQ value of 1.53 or LQ> 1.

\section{Shiff-share analysis}

Shift Share analysis is a very useful technique in analyzing the performance of the Southeast Sulawesi Province economic structure compared to the national economy. Through the Shift Share analysis will provide an overview of the economic performance of Southeast Sulawesi Province through three (3) stages of analysis that are interconnected with one another, namely: (1) The effect of national economic growth (National Share) (2) Proportional shift, and (3) Differential shift. The results of the Shif Share analysis of the Southeast Sulawesi economy can be seen in the following Table 5. The results of the National Share analysis show the effect of national economic growth on the economy of Southeast Sulawesi Province from 2015 to 2019, the following results are obtained. 
Table 5

National share analysis results, $2015-2019$

\begin{tabular}{|c|c|c|c|c|c|}
\hline \multirow[t]{2}{*}{ No. } & \multirow[t]{2}{*}{ Business field } & \multicolumn{4}{|c|}{ National Share } \\
\hline & & 2015-2016 & 2016-2017 & 2017-2018 & 2018-2019 \\
\hline 1. & Agriculture, Forestry and Fisheries & 852,02 & 926,25 & 998,96 & $1,032,81$ \\
\hline 2. & Mining and excavation & 793,92 & 782,49 & 899,83 & 934,45 \\
\hline 3. & Processing industry & 223,42 & 245,09 & 265,84 & 270,90 \\
\hline 4. & Procurement of Electricity and Gas & 1,80 & 2,09 & 2,26 & 2,23 \\
\hline 5. & $\begin{array}{l}\text { Water Supply, Waste Management, Waste } \\
\text { and Recycling }\end{array}$ & 7,20 & 7,90 & 8,07 & 8,29 \\
\hline 6. & Construction & 474,92 & 520,82 & 547,85 & 565,99 \\
\hline 7. & $\begin{array}{l}\text { Wholesale and Retail Trade; Car and } \\
\text { Motorcycle Repair }\end{array}$ & 440,13 & 495,92 & 540,08 & 559,74 \\
\hline 8. & Transportation and Warehousing & 159,63 & 182,73 & 199,83 & 211,24 \\
\hline 9. & $\begin{array}{l}\text { Provision of Accommodation and Food } \\
\text { and Drink }\end{array}$ & 21,30 & 23,04 & 24,94 & 25,86 \\
\hline 10. & Information and Communication & 82,52 & 93,76 & 103,67 & 109,03 \\
\hline 11. & Financial Services and Insurance & 79,78 & 92,51 & 98,61 & 97,91 \\
\hline 12. & Real Estate & 62,06 & 63,07 & 66,99 & 66,80 \\
\hline 13. & Company Services & 7,80 & 8,51 & 9,19 & 9,45 \\
\hline 14. & $\begin{array}{l}\text { Government Administration, Compulsory } \\
\text { Social Security and Defense }\end{array}$ & 202,94 & 208,30 & 221,11 & 227,43 \\
\hline 15. & Education Services & 174,89 & 191,39 & 201,08 & 210,26 \\
\hline 16. & Health Services and Social Activities & 36,32 & 38,83 & 40,95 & 42,53 \\
\hline 17. & Other services & 54,33 & 58,82 & 61,62 & 63,26 \\
\hline & amount & $3,675,1$ & $3,941,53$ & $4,290,92$ & $4,438,25$ \\
\hline
\end{tabular}

Source: BPS Prov. Southeast Sulawesi 2020 (Data processed and analyzed)

Based on the results of the national share analysis, all sectors show positive numbers every year. This shows that the increase in GRDP of Southeast Sulawesi Province from 2015 to 2019 was influenced by the national economic growth of Rp. 3,675,062 in 2016, of Rp. 3,941,531 in 2017, of Rp. 4,290,922 in 2018, and amounting to Rp.4,438,255 in 2019.

\section{Proportional shiff analysis}

The proportional shift analysis measures the relative change in the economic growth of Southeast Sulawesi Province compared to Indonesia's economic growth, so it can be seen whether the economy of Southeast Sulawesi Province is concentrated in sectors that are growing faster than the Indonesian economy. The results of the shiff share analysis based on the GRDP data of Southeast Sulawesi for 2015 to 2019 are as follows.

Table 6

Results of proportional shiff analysis, $2015-2019$

\begin{tabular}{llllll}
\hline \multirow{2}{*}{ No. } & Business field & \multicolumn{3}{l}{ Proportional Shiff } \\
\cline { 3 - 5 } & & $2015-2016$ & $2016-2017$ & $2017-2018$ & $2018-2019$ \\
\hline 1. & Agriculture, Forestry and Fisheries & $(281,07)$ & $(210,81)$ & $(246,55)$ & $(284,70)$ \\
2. & Mining and excavation & $(561,11)$ & $(681,16)$ & $(524,18)$ & $(707,95)$ \\
3. & Processing industry & $(34,47)$ & $(37,54)$ & $(46,06)$ & $(66,11)$ \\
4. & Procurement of Electricity and Gas & 128 & $(1,46)$ & 132 & $(437)$ \\
5. & Water Supply, Waste Management, Waste & $1,332,59$ & $(742)$ & 613 & 2,98 \\
& and Recycling & 17,468 & 177,54 & 97,45 & 82,53 \\
6. & Construction & $(88,09)$ & $(59,81)$ & $(21,32)$ & $(44,85)$ \\
7. & Wholesale and Retail Trade; Car and & & & & \\
\hline
\end{tabular}




\begin{tabular}{llllll}
\hline & Motorcycle Repair & & & \\
8. & Transportation and Warehousing & 76,63 & 123,39 & 72,98 & 57,81 \\
9. & Provision of Accommodation and Food & 576 & 1,55 & 2,47 & 4,07 \\
& and Drink & 63,09 & 84,30 & 37,11 & 95,06 \\
10. & Information and Communication & 61,77 & 7,30 & $(19,01)$ & 30,65 \\
11. & Financial Services and Insurance & $(4,23)$ & $(18,26)$ & $(21,88)$ & 9,46 \\
12. & Real Estate & 3,61 & 5,65 & 6,09 & 9,92 \\
13. & Company Services & $(74,06)$ & $(124,20)$ & 78,34 & $(16,22)$ \\
14. & Government Administration, Compulsory & $(41,46)$ & $(51,07)$ & 7,19 & 52,91 \\
& Social Security and Defense & 24,98 & 13,54 & 15,67 & 30,93 \\
15. & Education Services & 32,11 & 42,50 & 45,24 & 69,59 \\
16. & Health Services and Social Activities & 528,38 & $(729,28)$ & $(515,70)$ & $(674,41)$ \\
17. & Other services & Amount &
\end{tabular}

Source: BPS Prov. Southeast Sulawesi 2020 (Data processed and analyzed)

Table 6 above is the results of the proportional shiff analysis which shows that the economic sector is experiencing faster growth compared to the national economic growth for the period 2016 to 2019, namely: (1) 2016, the electricity and gas procurement sector, the water supply sector, waste management, waste and recycling, the construction sector, the transportation and warehousing sector, the accommodation and food supply sector, the information and communication sector, the financial and insurance services sector, the corporate services sector, the health sector and social activities and other service sectors (Bathelt et al., 2010; Roscoe et al., 2016). (2) In 2017, the construction sector, the transportation and warehousing sector, the accommodation and food supply sector, the information and communication sector, the financial and insurance services sector, the corporate services sector, the health sector and social activities and other service sectors. (3) In 2018, the electricity and gas procurement sector, the water supply sector, waste management, waste and recycling, the construction sector, the transportation and warehousing sector, the accommodation and food supply sector, the information and communication sector, the corporate services sector, the administration sector government, defense and social security, the health sector and social activities, the education service sector, and other service sectors. (4) In 2019, the water supply sector, waste management, waste and recycling, the construction sector, the transportation and warehousing sector, the accommodation and food supply sector, the information and communication sector, the financial and insurance services sector, the real sector, the corporate services sector, the health sector and social activities, the education service sector, and the service sector (Domenech et al., 2019; Barbero et al., 2012).

\section{Differential shiff analysis}

Differential shiff analysis determines how competitive the economic sector of Southeast Sulawesi Province is compared to the national one. The results of the shiff share analysis using the GRDP data of Southeast Sulawesi Province from 2015 to 2019 are shown in Table 7 below.

Table 7

Results of differential shiff analysis, $2015-2019$

\begin{tabular}{llllll}
\hline No. & Business field & \multicolumn{2}{l}{ Differential Shiff } \\
\cline { 3 - 6 } & & $2015-2016$ & $2016-2017$ & $2017-2018$ & $2018-2019$ \\
\hline 1. & Agriculture, Forestry and Fisheries & 770,77 & 337,76 & 478,84 & 284,41 \\
2. & Mining and excavation & $(572,50)$ & $1,870,09$ & 815,80 & $1,172,34$ \\
3. & Processing industry & 206,12 & 100,54 & 29,21 & 345,84 \\
4. & Procurement of Electricity and Gas & 3,45 & 1,81 & $(1,76)$ & 1,30 \\
5. & Water Supply, Waste Management, Waste & $(1,327,04)$ & $(6,97)$ & 238 & $(4,796)$ \\
& and Recycling & 344,47 & $(373,85)$ & 21,54 & 179,13 \\
6. & Construction & 684,61 & 229,34 & 174,08 & 348,79 \\
7. & Wholesale and Retail Trade; Car and & 196,36 & $(45,02)$ & 65,95 & $(84,77)$ \\
& Motorcycle Repair & & & & \\
8. & Transportation and Warehousing & & &
\end{tabular}




\begin{tabular}{llllll}
\hline 9. & Provision of Accommodation and Food & 9,27 & 3,38 & 4,87 & $(4,43)$ \\
and Drink & Information and Communication & 64,28 & $(22,08)$ & 23,66 & $(34,15)$ \\
11. & Financial Services and Insurance & 97,99 & $(17,16)$ & $(38,33)$ & 7,05 \\
12. & Real Estate & $(46,92)$ & 7,10 & $(11,66)$ & $(25,39)$ \\
13. & Company Services & 1,25 & $(4,13)$ & $(4,94)$ & $(9,56)$ \\
14. & Government Administration, Compulsory & $(52,45)$ & 84,29 & $(50,10)$ & $(142,10)$ \\
& Social Security and Defense & 166,80 & $(25,77)$ & 86,78 & 29,74 \\
15. & Education Services & $(16,90)$ & $(26,23)$ & $(2,25)$ & $(2,24)$ \\
16. & Health Services and Social Activities & $(5,78)$ & $(69,58)$ & $(39,94)$ & $(75,29)$ \\
17. & Other services & 523,76 & $2,043,52$ & $1,552,00$ & $1,985,81$ \\
& &
\end{tabular}

Source: BPS Prov. Southeast Sulawesi 2020 (Data processed and analyzed)

The results of the differential shiff analysis from 2015 to 2019 show a positive value. This shows that the economic sector in Southeast Sulawesi is competitive at the national level. The sectors that have the highest competitiveness are the mining and quarrying sector, the management industry sector and the agriculture, marine and fisheries sector. The results of the analysis of all economic sectors in Southeast Sulawesi Province have a positive shiff share value. This shows that there has been an increase in development performance in Southeast Sulawesi Province for the period 2015 to 2019.

\section{Classification typology analysis}

Classification Typology Analysis to determine the pattern and structure of economic growth for each business field in Southeast Sulawesi Province from 2015 to 2019, the results of the Classification Typology analysis are shown in Table 8 below.

Table 8

Results of Klassen Typology Analysis, 2015 - 2019

\begin{tabular}{|c|c|c|c|c|c|c|c|}
\hline \multirow[t]{2}{*}{ No. } & \multirow[t]{2}{*}{ Business field } & \multicolumn{2}{|c|}{ PDB Indonesia } & \multicolumn{2}{|c|}{ PDRB Prov. Sultra } & \multirow[t]{2}{*}{ Quadrant } & \multirow[t]{2}{*}{ Results } \\
\hline & & $\begin{array}{l}\text { Growth } \\
\text { Average }\end{array}$ & $\begin{array}{l}\text { Distribution } \\
\text { Average }\end{array}$ & $\begin{array}{l}\text { Growth } \\
\text { Average }\end{array}$ & $\begin{array}{l}\text { Distribution } \\
\text { Average }\end{array}$ & & \\
\hline 1. & $\begin{array}{l}\text { Agriculture, Forestry and } \\
\text { Fisheries }\end{array}$ & 3.71 & 12.70 & 6.27 & 5.92 & II & $\begin{array}{l}\text { Forward but } \\
\text { depressed }\end{array}$ \\
\hline 2. & Mining and excavation & 1.38 & 7.92 & 6.25 & 4.38 & II & $\begin{array}{l}\text { Forward but } \\
\text { depressed }\end{array}$ \\
\hline 3. & Processing industry & 4.16 & 21.19 & 7.58 & 8.98 & II & $\begin{array}{l}\text { Forward but } \\
\text { depressed }\end{array}$ \\
\hline 4. & $\begin{array}{l}\text { Procurement of Electricity } \\
\text { and Gas }\end{array}$ & 4.11 & 1.04 & 7.33 & 4.12 & I & $\begin{array}{l}\text { Fast forward, } \\
\text { fast growing }\end{array}$ \\
\hline 5. & $\begin{array}{l}\text { Water Supply, Waste } \\
\text { Management, Waste and } \\
\text { Recycling }\end{array}$ & 6.59 & 0.07 & 4.67 & 4.08 & III & Fast growing \\
\hline 6. & Construction & 5.97 & 9.95 & 6.42 & 7.08 & III & Fast growing \\
\hline 7. & $\begin{array}{l}\text { Wholesale and Retail Trade; } \\
\text { Car and Motorcycle Repair }\end{array}$ & 4.52 & 13.27 & 8.26 & 8.26 & III & Fast growing \\
\hline 8. & $\begin{array}{l}\text { Transportation and } \\
\text { Warehousing }\end{array}$ & 7.35 & 4.07 & 8.51 & 6.98 & I & $\begin{array}{l}\text { Fast forward } \\
\text { and fast } \\
\text { growing }\end{array}$ \\
\hline 9. & $\begin{array}{l}\text { Provision of Accommodation } \\
\text { and Food and Drink }\end{array}$ & 5.52 & 3.01 & 6.29 & 5.95 & I & $\begin{array}{l}\text { Fast forward } \\
\text { and fast } \\
\text { growing }\end{array}$ \\
\hline 10. & $\begin{array}{l}\text { Information and } \\
\text { Communication }\end{array}$ & 8.73 & 5.04 & 9.32 & 8.27 & I & $\begin{array}{l}\text { Fast forward } \\
\text { and fast }\end{array}$ \\
\hline
\end{tabular}




\begin{tabular}{|c|c|c|c|c|c|c|c|}
\hline 11. & $\begin{array}{l}\text { Financial Services and } \\
\text { Insurance }\end{array}$ & 6.29 & 3.99 & 7.19 & 7.12 & I & $\begin{array}{l}\text { growing } \\
\text { Fast forward } \\
\text { and fast } \\
\text { growing }\end{array}$ \\
\hline 12. & Real Estate & 4.38 & 2.92 & 2.87 & 5.54 & III & Fast growing \\
\hline 13. & Company Services & 8.67 & 1.75 & 6.29 & 7.43 & III & Fast growing \\
\hline 14. & $\begin{array}{l}\text { Mandatory Government } \\
\text { Administration, Defense and } \\
\text { Social Security }\end{array}$ & 4.23 & 3.37 & 3.34 & 6.23 & III & Fast growing \\
\hline 15. & Education Services & 4.80 & 3.11 & 6.56 & 7.37 & II & $\begin{array}{l}\text { Forward but } \\
\text { pressed }\end{array}$ \\
\hline 16. & $\begin{array}{l}\text { Health Services and Social } \\
\text { Activities }\end{array}$ & 7.79 & 1.11 & 6.21 & 7.78 & III & Fast growing \\
\hline 17. & Other services & 9.06 & 1.73 & 5.10 & 8.22 & III & Fast growing \\
\hline
\end{tabular}

Source: BPS Prov. Southeast Sulawesi 2020 (Data processed and analyzed)

The results of the classification typology analysis show: (1) Quadrant I, a fast-growing and fast-growing sector: the electricity and gas supply sector, the transportation and warehousing sector, the accommodation and food supply sector, the information and communication sector, and the financial services and insurance sector (2) Quadrant II, advanced but depressed sectors: agriculture, forestry and fisheries sector, mining and quarrying sector, management industry sector, and education service sector. (3) Quadrant III, Fast growing sector: water supply sector, waste management, waste and recycling, construction sector, wholesale and retail trade sector; car and motorcycle repair, government administration sector, defense and social security, health services sector and other social activities and service sectors. The results of the Klasen typology analysis show that there is no economic sector in Southeast Sulawesi Province which is classified as a relatively underdeveloped sector (Tarigan, 2005; Emilia del Pino et al., 2006).

\section{Conclusion}

The results of the analysis of the development performance of Southeast Sulawesi Province from 2015 to 2019 saw an increase in performance in all sectors of the economy. The sectors that have the highest competitiveness and performance are in the sectors (1) Agriculture, Forestry and Fisheries (2) Mining and Quarrying, (3) Construction, (4) Wholesale and Retail Trade; Repair of Automobiles and Motorcycles, and (5) Manufacturing Industry. These five sectors are the economic base sectors that provide the largest contribution to the GRDP of Southeast Sulawesi Province, so it is necessary to develop strategies and policies that place these five sectors as the leading sectors in the economic development of the Southeast Sulawesi Province.

\section{Recommendation}

- Increasing development performance is both an objective and an indicator of the success of development in Southeast Sulawesi Province. Therefore, it is necessary to develop strategies and policies that place the basic sectors as leading sectors in economic development, as well as being a strong instrument in the effort to increase economic growth and development performance in Southeast Sulawesi Province.

- Development performance is influenced by the economic growth of Southeast Sulawesi Province which results in a continuous increase in per capita income for the population. Therefore, the development planning strategy needs to focus on the development of an integrated and integrated economic infrastructure based on competitive advantages in various regions supported by quality and competitive human resources.

- The big capital for development is the existence of capital (social capital). Strengthening social capital is very important in efforts to increase economic growth and improve development performance in Southeast Sulawesi Province. Through social networking - a network of group organizations to support the collective action of development in empowering local communities. Optimization of social capital is an opportunity to increase economic growth which must be continuously strengthened to support the improvement of development performance in Southeast Sulawesi Province. 


\section{References}

Barbero, J. L., Casillas, J. C., Ramos, A., \& Guitar, S. (2012). Revisiting incubation performance: How incubator typology affects results. Technological Forecasting and Social Change,79(5), 888-902. https://doi.org/10.1016/j.techfore.2011.12.003

Bathelt, H., Kogler, D. F., \& Munro, A. K. (2010). A knowledge-based typology of university spin-offs in the context of regional economic development. Technovation, 30(9-10), 519-532. https://doi.org/10.1016/j.technovation.2010.04.003

Domenech, T., Bleischwitz, R., Doranova, A., Panayotopoulos, D., \& Roman, L. (2019). Mapping Industrial Symbiosis Development in Europe_typologies of networks, characteristics, performance and contribution to the Circular Economy. Resources, conservation and recycling, 141, 76-98. https://doi.org/10.1016/j.resconrec.2018.09.016

Dong, Y., Wang, X., Jin, J., Qiao, Y., \& Shi, L. (2014). Effects of eco-innovation typology on its performance: Empirical evidence from Chinese enterprises. Journal of Engineering and Technology Management, 34, 78-98. https://doi.org/10.1016/j.jengtecman.2013.11.001

Emilia del Pino, M., Rosado, R. H., Azuela, A., Guzmán, G., Argüelles, D., Rodríguez, C., \& Rosado, G. M. (2006). Effect of controlled volumetric tissue heating with radiofrequency on cellulite and the subcutaneous tissue of the buttocks and thighs. Journal of drugs in dermatology: JDD, 5(8), 714-722.

Faucheux, S., \& Nicolaï, I. (2011). IT for green and green IT: A proposed typology of eco-innovation. Ecological economics, 70(11), 2020-2027. https://doi.org/10.1016/j.ecolecon.2011.05.019

Geels, F. W., \& Schot, J. (2007). Typology of sociotechnical transition pathways. Research policy, 36(3), 399-417. https://doi.org/10.1016/j.respol.2007.01.003

Heriyanto, M., Yusri, A., Muchid, M., \& Wirawan, B. A. (2020). Tenure Amnesty for the Upstream Oil and Gas Industry in the Forest Area. International Research Journal of Management, IT and Social Sciences, 7(5), 160170.

Lopez-Carreiro, I., \& Monzon, A. (2018). Evaluating sustainability and innovation of mobility patterns in Spanish cities. Analysis by size and urban typology. Sustainable Cities and Society, 38, 684-696. https://doi.org/10.1016/j.scs.2018.01.029

Park, S., \& Bae, Z. T. (2004). New venture strategies in a developing country: Identifying a typology and examining growth patterns through case studies. Journal of Business Venturing, 19(1), 81-105. https://doi.org/10.1016/S0883-9026(02)00110-6

Roscoe, S., Cousins, P. D., \& Lamming, R. C. (2016). Developing eco-innovations: A three-stage typology of supply networks. Journal of Cleaner Production, 112, 1948-1959. https://doi.org/10.1016/j.jclepro.2015.06.125

Schumann, J. H., Wünderlich, N. V., \& Wangenheim, F. (2012). Technology mediation in service delivery: A new typology and an agenda for managers and academics. Technovation, 32(2), 133-143. https://doi.org/10.1016/j.technovation.2011.10.002

Tarigan, R. (2005). An evaluation of the relationship between alignment of strategic priorities and manufacturing performance. International Journal of Management, 22(4), 586. 